\title{
Strategi Badan Perencanaan Pembagunan Daerah Penelitian Dan Pengembangan Bapedalitbang Di Kabupaten Kuantan Singingi
}

\author{
${ }^{1}$ Annisa Putri. M, ${ }^{2}$ Seno Andri \\ ${ }^{12}$ Program Studi Magister Ilmu Administrasi,Universitas Riau, Indonesia \\ e-mail: senoandri@lecturer.unri.ac.id
}

\begin{abstract}
Abstrak
Penelitian ini bertujuan untuk: 1) Mengetahui strategi Badan Perencanaan Pembagunan Daerah Penelitian dan pengembangan (Bappedaltbang) di Kabupaten Kuantan singingi 2) Mengetahui faktorfaktor penghambat strategi Badan perencanaan pembagunan Daerah Penelitian dan Pengembangan (Bappedalitbang) Di kabupaten kuantan singingi. Penelitian ini Mengunakan Model Pendekatan Penelitian Deskriptif Kualitatif. Data Primer diperoleh langsung melalui wawancara dari key informan, sedangkan Data Sekunder diperoleh Dokumen penelitian yaitu,Kepala Bappedalitbang,Kasubag Program Kasubag serta kasubag lain nya.Hasil Penelitian menunjukan bahwa Belum Terlaksannya Secara Maksimal Strategi Badan Perencanaan Pembagunan Daerah Penelitian dan Pengembangan (Bappedalitbang) Di kabupaten kuantan singingi.
\end{abstract}

Keywords: Strategi Organisasi, Perencanaan,Pembagunan,Pengembangan

\begin{abstract}
This study aims to: 1) Know the strategy of the Regional Development Planning Agency Research and development (Bappedaltbang) in Kuantan Regency singing 2) Know the inhibiting factors of the strategy of the Regional Planning and Development (Bappedalitbang) development planning in Kuantan singingi district. This study uses a qualitative descriptive research approach model. Primary data obtained directly through interviews from key informants, while secondary data obtained by research documents, namely the Head of Bappedalitbang, the Head of the Head of the Head of the Head of the Program and other Head of Subdivisions. Kuantan singing.
\end{abstract}

Kata Kunci : Organizational Strategy, Planning, Development, Development

\section{PENDAHULUAN}

Kabupaten kuantan singingi merupakan salah satu kabupaten di propinsi Riau yang berdiri bedasarkan UU No 53 tahun 1999.dalam pelaksanaan dalam pemerintahnya kabupaten kuatan singingi memiliki visi Pemerintah Kabupaten Kuantan Singingi Tahun 2021 adalah,Terwujudnya Kebupaten Kuantan Singingi yang Unggul, Sejahtera dan Agamis di Propinsi Riau Tahun 2021" misi (1). Peningkatan upaya pemerintah yang bersih sebagai langkah mewujudkan terciptanya pemerintah yang baik di kabupaten kuantan singingi. (2) Mengefektifkan dan mengoptimalkan kualitas pendidikan dan kesehatan masyarakat Kabupaten Kuantan singingi (3) Mempercepat pertumbuhan hubugan yang harmonis sekaligus meningkatan respondan kepekaan aparat pemerintah Kabupaten Kuantan Singingi terhadap lapisan masyarakat

Musrenbang adalah Forum Perencanaan (program) yang dilaksanakan oleh Lembaga Publik yaitu Pemerintah Desa, bekerja sama dengan warga dan Pemangku kepentingan lainnya. Musrenbang yang 
bermakna akan mampu Membangun kesepahaman tentang kepentingan dan kemajuan Desa,dengan 5 cara memotret Potensi dan Sumber-Sumber Pembangunan yang tidak tersedia baik dari dalam maupun dari luar Desa. Musyawarah Perencanaan Pembangunan (Musrenbang) telah menjadi istilah Popular dalam Penyelenggaraan Perencanaan Pembangunan dan Penganggaran di Daerah, bersamaan dengan penerbitan Undang-Undang Nomor 25 Tahun 2004 tentang Sistem Perencanaan Pembangunan Nasional (SPPN). Strategi Bappedalitbang Kabupaten Kuantan Singingi dalam pelaksanaan Musrenbang Kabupaten/Kota juga mengacu kepada Panduan Penyelenggaan Musyawarah Perencanaan Pembangunan Kabupaten/Kota dan dalam pelaksanaannya terdapat adanya Fenomena yang merupakan Masalah Pokok pada penelitian ini adalah sebagai berikut:

1. Seharusnya dengan Adanya Musrembang Masyarakat lebih Mudah dalam Menyampaikan Aspirasinya, akan tetapi kenyataan masih Banyak usulan program yang berasal dari Kelompok penguasa yang lebih didahulukan dengan Membelakangkan usulan Program dari Aspirasi Masyarakat.

2. Masih Banyak usulan-usulan Program dari Hasil musrembang Desa dan kecematan yang tidak telaksana.

3. Pada Tahap Pasca Musrenbang Kabupaten/kota, Hasil-Hasil Musrenbang Kabupaten/Kota yang Masuk dalam finalisasi Dokumen RKPD telah diDokumentasikan terlebih Dahulu dan Rapat kerja hasil hanya pengukuhan saja dan menyampaikan hasil yang dimasukkan dalam Dokumen finalisasi sehingga agenda tentang Tanggapan setiap Bidang untuk Masukan-Masukan Hasil Musrenbang Terutama masukan yang menjadi prioritas untuk dimasukkan ke dalam finalisasi Dokumen RPKP tidak dilaksanakan.

Tiga Pilar dikabupaten Kuantan singingi Paket Proyek tersebut berupa bagunan ialah:

1. Pembagunan Pasar Tradisional Berbasis Modern

2. Hotel Kuansing, dan

3. Pembagunan universitas islam kuantan singingi (uniks).

(pelita Riau .com).

Diperkirakan Pembagunan proyek Tiga Pilar ini telah Menghabiskan Dana APBD kuansing yang Nilainya sangat fatastis yaitu sebesar Rp 102 M miliyar lebih. Bedasakan data yang diperoleh Pembagunan Pasar Tradiisional Berbasis Modern Menghabiskan APBD Kuansing Pada tahun 2014 dan 2015 namun saat ini Belum selesai dana sebesar Rp 4,4 M, Pembagunan Hotel Kuansing Rp 47 M dan uniks Rp 5. Pasar Modern Permasalahan terkait dengan Hotel yang Bapak Bupati menjelaskan Pemerintah Daerah telah melakukan Pembayaran Hasil pekerjaan yang telah di laksanakan oleh Pihak ketiga, bedasarkan Hasil Audit. Namun kata Bupati Hasil pekerjaan tersebut belum memadai untuk memfungsikan Bagunan Hotel Kuangsing. sementara itu wagub (pelita Riau.com)

Hotel kuansing Belum selesai Dari penemuan diatas dapat dijelaskan bahwa Pemerintahan telah melakukan Pembayaran Tentang Terbengkalai Masalah Pembagunan dengan dari hasil Pekerjaan, yang dilakukan oleh pihak Bedasarkan Hasil Audit untuk Hasil pekerjaan Belum Memadai sehingga untuk mempungsikan Bagunan Hotel kuansing Kampus uniks Belum ditempati sedangkan untuk pasar Modern sudah ditempati pedagang.

Robinson (2008:2), Strategi adalah rencana berskala besar, dengan orientasi masa Depan, guna berinteraksi dengan kondisi persaingan untuk mencapai tujuan. Perusahaan dari definisi tersebut, dapat di simpulkan bahwa pengertian dari Strategi adalah sebuah tindakan proses perencanaan untuk mencapai tujuan yang telah di tetapkan, dengan melalukan hal-hal yang besifat terus menerus sesuai keputusan bersama dan berdasarkan sudut pandang kebutuhan pelanggan.

Menurut Tjiptono (2006:3) istilah Strategi berasal dari bahasa Yunani yaitu strategia yang artinya seni atau ilmu untuk menjadi seorang jendral. Strategi juga bisa diartikan suatu Rencana 
untuk pembagian dan penggunaan kekuatan militer pada Daerah -Daerah tertentu untuk mencapai tujuan tertentu. Rangkuti (2013:183) Berpendapat bahwa Strategi adalah Perencanaan induk yang komprehensif, yang menjelaskan bagaimana perusahaan akan mencapai semua tujuan yang telah di tetapkan berdasarkan misi yang telah di tetapkan Nama dan berdasarkan sudut pandang kebutuhan pelanggan.

Pengertian Strategi dalam konteks Organisasi adalah penetapan berbagai Tujuan dan sasaran jangka panjang yang bersifat mendasar bagi sebuah organisasi yang dilanjutkan dengan penetapan Rencan aktivitas dan pengalokasiaan sumber Daya yang diperlukan guna mencapai baerbagi sasaran tersebut. Roudledge seuler dalam yunus (2016:5) merumuskan suatu Organisasi antara Sumber Daya dan keahlian internalnya dan kesempatan dan Resiko yang terbentuk melalui lingkungan ekternal. Strategi disusun dan dimplementasikan untuk mencapai berbagai tujuan yang telah ditetapkan, sekaligus mempertahankan dan memperluas aktivitas organisasi pada bidang bidang baru dalam Rangka merespon lingkungan minsalnya perubahan permintaan perubahan sumber pasokan fluktuasi kondisi Ekonomi Perkembangan Teknologi baru dan aktivitas para pesaing

Robbins dalam Linda Hetri, kirmizi dan Desmiyanti (20015:32) pengertian Strategi dalam konteks Organisasi adalah Penepatan berbagai Tujuan dan Sasaran Jangka Panjang yang bersifat Mendasar bagi sebuah Organisasi, yang dilanjutkan dengan Penetapan Rencana aktivitas dan pengalokasian Sumber Daya yang diperlukan guna mencapai berbagai sasaran tersebut.

Perencanaan strategis semakin menjadi kebutuhan, mengingat lingkungan selalu berubah dan masa Depan kian sulit dipredisikan. Oragnisasi yang baik adalah yang memiliki Tujuan (goals) jelas bedasarkan visi misi yang disepakati oleh para pendirinya. Untuk mewujudkan tujuan tersebut dibutuhkan cara untuk mencapainya, yang lazim disebut sebagai strategi. selanjutnya disusun Rencana (plan) seperangkat kebijakan (policies), tahap tahap Pencapaian,organisasi dan personalia yang mengisinya, aggaran dan program aksi.

Menurut fred R. David (2006:25), Perencanaan Startegis adalah proses yang sulit, kompleks dan Butuh Partisipasi yang membawa Organisasi menuju teritori asing. Ia tidak menyediakan Resep yang langsung dapat digunakan untuk sukses sebaliknya ia membawa Organisasi ke dalam suatu perjalanan dan menawarkan kerangka kerja untuk menjawab pertanyaan dan memecahkan masalah.

Michael Allison \& jude kaye (2013:1), perencanaan strategis adalah sebuah alat manajemen, alat itu digunakan untuk satu maksud saja yaitu, menolong organisasi melakukan tugasnya dengan lebih baik. Perencanaan strategis dapat membantu organisasi memfokuskan visi dan Prioritasnya sebagai jawaban terhadap lingkungan yang berubah untuk mematikan agar angota anggota organisasi itu bekerja kearah Tujuan yang sama.

\section{METODE}

Tipe penelitian yang digunakan adalah penelitian Deskiptif Kualitatif. Informan penelitian adalah unsur pihak Kasubag umum,Kasubag program, kabid bidang IV, kasubid, kabid Perencanaan dan Pembagunan dinas Badan Perencanaan dan Pembagunan daerah penelitian dan pengembangan, pihak kampus yang terlibat dalam Pembagunan Teknik pengumpulan data adalah wawancara,observasi, dan Dokumentasi. Teknis Analisis Data yang digunakan adalah Analisis Deskriptif. Melalui Teknik ini, akan digambarkan kategori-kategori yang Relevan dengan Tujuan Penelitian dan penafsiran terhadap hasil Analisis Deskriptif dengan berpedoman pada Teori yang sesuai. 


\section{HASIL DAN PEMBAHASAN}

Strategi merupakan sejumlah tindakan yang terintegrasi dan terkoordinasi yang diambil untuk mengeploitasi kompetensi inti serta memperoleh keunggulan besaing.Sedangkan ada juga yang berpendapat bahwa strategi adalah prioritas atau arah keseluruhan yang luas diambil oleh organisasi atau sebagai pilihan-pilihan tentang bagaimana cara yang terbaik untuk mencapai misi organisasi. Penyusunan strategi yang dilakukan juga untuk mempermuda organisasi mencapai tujuan yang ditetapkan. Sedangkan Langkah-langkah tersebut merupakan pedoman dan petunjuk sebagai acuan bagi setiap implementor untuk bisa melaksanakan dengan dan sesuai mencapai tujuan yang ditetapkan. Maka dengan ada strategi perencaan pembagunan apabila inggin merealisasikan tujuan yang ditetapkan langkah tersebut merupakan pedoman dan petunjuk sebagai acuan bagi setiap implementator untuk bisa melaksanakan setiap kegiantan sesuai dengan yang telah disusun. Sehingga apabila menemui hambanbatan-hambatan dan rintangan dalam melaksanakan strategi tesersebut dapat segera untuk dicari solusinya.

\subsection{Strategi inovasi}

Strategi inovasi Merupakan suatu bentuk perubahan yang dilakukan untuk meningkatkan inisiatif yang dimiliki oleh organisasi. Strategi inovasi digunakan oleh organisasi dengan cara membuat produk atau jasa yang berbeda dari persaing, umumnya terpokus pada penawaran sesuatu produk yang baru dan berbeda dari pesaing, umumnya terpokus pada penawaran sesuatu produk atau jasa yang berbeda pertama, pekerjaan-pekerjaan menuntut interaksi, dan koordinasi yang erat antara kelompok-kelompok individu. Kedua, penilain kinerja yang lebih mencerminkan pencapaian tujuan bedasarkan kelompok untuk jangkah lebih waktu panjang. Ketiga pekerjaan yang memungkinkan karyawan megembangkan keahliannya yang dapat digunakan pada posisi lainya didalam organisasi. Keempat, system kompensasi yang menekankan pada keadilan internal dari pada keadilan ekternal menurut pasar. Kelima, tingkat gaji yang cenderung rendah tapi memungkinkan karyawan menjadi pemilik saham dan memiliki kelulasaan memiliki bauran komponen gaji yang medasar paket upah mereka.

strategi inovasi akan dinilai dari koordinasi antar unit kerja, penyusunan pengembangan karier, pemberian insentif kerja dan, penetapan standar kerja. Pengembangan koordinasi antar unit kerja merupakan upaya yang segera dilaksanakan oleh organisasi,bila mengingikan setiap unit kerja yang ada memiliki komitmen political will untuk bersama sama dalam merealisasikan tujuan organisasi.

\subsection{Strategi Peningkatan Kualitas SDM}

Pokus Strategi Peningkatan Kualitas adalah pada Peningkatan Kualitas Produksi Jasa Manajemen Sumber Daya Manusia memegang peranan penting dalam Mencapai Keunggulan Bersaing melalui strategi Peningkatan Kualitas maka Manusia adalah Pertama Deskripsi Pekerjaan yang Relative tetap dan Jabatan secara Eksplisit kedua tingkatan Partisipasi Karyawan dalam Keputusan yang Melawan Kondisi kerja dan Pekerjaan itu sendiri ketiga Bantuan Bauran antara kriteria individu dan kelompok untuk Penilaian kinerja haruslah Berjangka pendek.

penerapan strategi kualitas perlu melakukan penilaian kinerja yang dihasilkan oleh aparatur. Oleh karna penilaian yang dilakukan ini organisasi bisa melaksanakan Evaluasi terhadap pelaksanaan tugas yang dibebankan dan juga kepada aparatur tersebut.

\subsection{Pembahasan}

Perencanaan pembagunan Daerah strategi perencaan Pembagunan apabila inggin merealisasikan tujuan yang ditetapkan langkah tersebut merupakan pedoman dan petunjuk sebagai acuan bagi setiap implementator untuk bisa melaksanakan setiap kegiantan sesuai dengan yang telah disusun. Sehingga apabila menemui hambanbatan-hambatan dan rintangan dalam melaksanakan strategi tesersebut dapat 
segera untuk dicari solusinya. Oleh karena itu penyusunan strategi yang dilakukan sangatlah peting bisa melaksanakan setiap kegiatan atau program yang dikerjakan oleh organisasi dalam upaya mewujudkan tujuan yang telah ditetapkan. factor-factor yang Menghambat Strategi Badan Perencanaan Pembagunan Daerah Penelitian dan Pengembangan Bappedalitbang di Kabupaten Kuantan Singingi. Yaitu:

1. Penempatan Pegawai yang tidak Sesuai dengan Kebutuhan Suatu Kebijakan organisasi yang Menyalurkan Kemampuan Karyawan atau Pegawai pada Posisi Pekerjaan yang paling sesuai dengan Kebutuhan Jabatan, Pengetahuan, Keterampilan dan Kemampuan Karyawan tersebut agar memperoleh kepuasan kerja dan prestasi yang belum optimal. Penempatan kerja Karyawan merupakan tidak lanjutnya dari kebijakansanaan penerimaan karyawan. Prinsip Penempatan Kerja harus dilaksanakan Secara tepat dan Konsekuen agar karyawan dapat Bekerja sesuai dengan keahlian masing masing.

2. Belum tertatanya system pengelolaan asset dengan baik. Kurangnya ketersedian data dilapangan merupakan tebatasnya peralatan saat pendukung yang tersedia ketika penijauan ini menyebabkan pengelolan asset dengan kurang baik akibat keterbatasan dana untuk pengelolaan asset daerah yang di kelolah dinas BPKAD.

3. Belum optimalnya peran aktif dari SKPD terhadap perencanaan Kurangnya koordinasi dengan stakeholders dalam penyusunan Program pembagunan Tahunan sehingga penyusunan SKPD dapat dilaksanakan terjadi tidak tepat waktu.

4. Aplikasi perencanaan yang belum ada dan maksud dengan terlaksananya perencanaan Belumnya terlaksananya perencanaan secara e-planning dengan itu akan dijelaskan.

5. Pemanfaatan Sumber Daya alam yang masih belum tepat maksudnya femanfaatan Sumber Daya Alam yang dilakukan masih belm tepat dan tidak sesuai dengan penempatanya dan masih Masih kurangnya aparatur.

6. Jabwal perencanaan sering tidak tepat waktu maksudnya perencanaan yang sering tidak tepat waktu maksudnya jabwal yang tidak sesuai dengan perencanaan dan system bisa tidak sesuai.

7. Koordinasi dengan stakeholder dibidang data masih kurang. Ialah siapa yang memberikan dampak dan/atau yang terkena oleh dampak dari suatu program, kebijakan, dan/atau pembangunan. Mereka bisa sebagai individu, kelompok, komunitas, atau suatu lembaga yang terdapat dalam setiap tingkat golongan masyarakat.

Strategi inovasi Merupakan suatu bentuk perubahan yang dilakukan untuk meningkatkan inisiatif yang dimiliki oleh organisasi. Strategi inovasi digunakan oleh organisasi dengan cara membuat produk ataujasa yang berbeda dari persaing, umumnya terpokus pada penawaran sesuatu produk yang baru dan berbeda dari pesaing, umumnya terpokus pada penawaran sesuatu produk atau jasa yang berbedai pertama, pekerjaan-pekerjaan menuntut interaksi, dan koordinasi yang erat antara kelompok-kelompok individu. Kedua, penilain kinerja yang lebih mencerminkan pencapaian tujuan bedasarkan kelompok untuk jangkah lebih waktu panjang. Ketiga pekerjaan yang memungkinkan karyawan megembangkan keahliannya yang dapat digunakan pada posisi lainya didalam organisasi.

Strategi Peningkatan Kualitas SDM Fokus Peningkatan Kualitas Produksi Jasa Manajemen Sumber Daya Manusia memegang peranan penting dalam Mencapai Keunggulan Bersaing melalui strategi Peningkatan Kualitas maka Manusia adalah Pertama Deskripsi Pekerjaan yang Relative tetap dan Jabatan secara Eksplisit kedua tingkatan Partisipasi Karyawan dalam Keputusan yang Melawan Kondisi kerja dan Pekerjaan itu sendiri ketiga Bantuan Bauran antara kriteria individu dan kelompok untuk Penilaian kinerja haruslah Berjangka pendek. 


\section{KESIMPULAN}

Strategi Badan Perencanaan Pembagunan Daerah (Bappedalitbang) di Kabupaten Kuantan Singingi adalah cukup baik. hal ini Menerapkan bahwa dinas Perencanaan Pembagunan Daerah Kabupaten Kuantan Singingi Masih Cukup Mampu Melaksanakan Strategi yang telah disusun untuk melakukan Perencanaan Pembagunan. Bappedalitabang dimana Strategi inovasi yang dilaksanakan berupaya Memberikan Rasangan kepada implementor untuk bisa Meningkatkan inisiatifnya dalam melakukan penerimaan Perecanaan Pembagunan Daerah. Oleh karena itu Strategi inovasi yang dilakukan meliputi koordinasi antar unit kerja, Pegembangan Keahlian kerja, Penyusunan Pengembangan Karier kerja, Pemberian insentif Kerja dan Penetapan Standar Kerja. Sedangkan Strategi Peningkatan Kualitas ini mulai dari Penjabaran Deskipsi Kerja, Partisipasi dalam Pengambilan Keputusan, Penilaian Pekerjaan keseragama,Perlakuan serta Pelatihan dan Pengembangan Kualitas. Dari Hasil Penelitian dan Pembahasan yang dilakukan, maka peran aktif dari SKPD terhadap Perencanaan, Pemanfaatan SumberDaya Alam yang Masih Belum Tepat.

\section{SARAN}

Saran dari hasil penelitian yang dilakukan maka ditemukan faktor yang Menghambat Strategi Orgaisasi Badan Perencanaan Pembagunan Daerah (Bappedalitbang) di Kabupaten Kuantan Singingi yaitu Penempatan Pegawai yang tidak sesuai dengan Kebutuhan, Belum Tertatanya sistem Pengelolaan Asset dengan baik, Belum Optimalnya Peran aktif dari SKPD terhadap Perencanaan, Pemanfaatan Sumber Daya Alam yang Masih Belum Tepat. Oleh sebab itu Bappedalitbang harus berupa untuk dapat memperbaiki manajemen untuk dapat memperbaiki kinerja organisasi. 


\section{DAFTAR PUSTAKA}

[1] Achmad sobirin, 2002. Budaya Organisasi Pengertian Makna dan Aplikasinya dalam kehidupan organisasi.

[2] Adam Ibrahim indrawijaya 2014. Teori prilaku dan Budaya organisasi menger. Bandung

[3] Adam Ibrahim indrawijaya. 2009. Prilaku Organisasi; Bandung

[4] Bratakusuma, dkk. 2000. Perencanaan Pembangunan Daerah, Strategi menggali Potensi

[5] Hasibuan, Melayu, 1998. Manajemen Sumber Daya Manusia, Penerbit Bumi Aksara. Jakarta.

[6] Miftah thoha 2011. Prilaku Organisasi Konsep Dasar dan Aplikasinya Jakarta

[7] Riyadi Dan D, Supriyadi Bratakusumah, 2005. Perencanaan Pembangunan Daerah, PT. Gramedia Pustaka Utama, Jakarta.

[8] Siagian, Sondang P, 2008. Manajemen Sumber Daya Manusia. PT. Bumi Aksara, Jakarta.

[9] Simamora Henry 2013 Manajemen Sumber Daya Manusia Jakarta

[10] Sumodiningrat, Gunawan. 2015. Pembangunan Daerah dan Pemberdayaan Masyarakat 